\title{
Explaining Rising Returns to Education in Urban China in the 1990s ${ }^{*}$
}

\author{
Xuejun Liu, Beijing Normal University \\ Albert Park, University of Oxford \\ Yaohui Zhao, Peking University
}

July 2008

\begin{abstract}
We analyze household survey and census data from 6 provinces to study the demand and supply determinants of rising returns to education in urban China during the 1990s. We find that the increase in general technical efficiency and industrial wage rents are the major forces driving up the relative wages of more educated workers; shifts in labor supply help negate the growing wage differentials between college and high school graduates but enlarge wage differentials between senior and junior high school graduates in the late 1990s; and changes in product demand reduce educational wage differentials but are relatively unimportant.
\end{abstract}

\footnotetext{
* Correspondence author: Albert Park, Institute for Chinese Studies, University of Oxford, Walton Street, OX1 2HG, United Kingdom, albert.park@economics.ox.ac.uk, 44 (0)1865 280774. Email addresses of coauthors: Liu Xuejun: liuxuejun@ccer.edu.cn; Yaohui Zhao: yhzhao@ccer.edu.cn. This research is supported by Key Project Fund for Key Research Base in Humanities and Social Sciences, Ministry of Education, China.
} 


\section{Introduction}

Wage inequality in urban China expanded rapidly in the 1990s due in part to increasing returns to education (Park et al., 2008). Based on repeated cross-sectional data between 1988 and 2001 drawn from urban household surveys in 6 provinces, Zhang et al. (2005) find that the returns to a year of schooling increased from only 4.0 percent in 1988 to 10.2 percent in 2001 . Most of the rise in the returns to education occurred after 1992 and reflected an increase in the wage premium for higher education. The higher returns to education are observed within groups defined by sex, work experience, region, or ownership.

Rising wage differentials among those with different levels of educational attainment have been observed in countries around the world. For example, in the U.S., the increase in wage differential between skilled workers and less-skilled workers is generally viewed as the main cause of rising wage inequality in the 1980s (Katz and Murphy 1992; Bound and Johnson 1992; Krueger,1993; Acemoglu, 2002). ${ }^{1}$ The literature from developed countries has suggested several explanations: rising demand for skilled workers due to skill-biased technical change, rising demand for skilled workers due to international trade, and institutional changes (i.e., the decline of unions) that reduce the protection of less skilled workers. $^{2}$

Similar forces are likely to exist in China. Institutional reforms that liberalized wage-setting in state-owned enterprises (SOEs) combined with increasing competition from the rapidly growing non-state sector undermined the previously centralized wage-setting scheme that compressed the wage structure in the central planning and early reform periods, resulting in higher rewards to human capital. By reentering the world

\footnotetext{
${ }^{1}$ All though it is generally accepted that the rise in wage inequality in the U.S. labor market during the 1980s is mainly attributed to skill-biased technical change(SBTC), a number of challenges to the SBTC hypothesis have emerged recently (Card and DiNardo, 2002; Lemieux, 2007).

2 Among many studies, notable contributions include Katz and Murphy (1992), Bound and Johnson (1992), Juhn et al. (1993), Krueger (1993), Freeman (1993), Freeman and Katz (1994), Borjas and Valerie (1995), DiNardo, Fortin and Lemieux (1996), Autor, Katz, and Kruger (1998), Acemoglu (2002), and Lemieux (2007).
} 
market, China may have experienced changes in the demand for skills. Technological advances also have been substantial, fueled in part by large inflows of FDI. It is not clear, however, whether these forces have had the same effects in China as in developed countries. For example, international trade in theory should increase the demand for products that intensively use low-skilled workers who are relatively abundant in China. But this may not b e the case if goods produced by relatively high-skilled workers in the U.S. are produced by relatively high skilled workers in China due to differences in the skill distribution of workers or technologies employed in the two countries.

In this paper, we evaluate the effects of institutional changes, technological change, the change in labor demand due to shifts in product demand and relative supply of skilled labor on rising skill premiums. We focus on the wage differential between workers with college education and above, senior high school education and junior high school education and below. Methodologically, we follow the demand and supply framework of Bound and Johnson (1992), modified to fit the situation in China.

The remainder of the paper is organized as follows. Section II describes the data and the trends in wage differentials across educational groups during the 1990s. Section III presents the analytical framework, Section IV reports the empirical results, and Section V concludes.

\section{Data and Descriptive Evidence of Rising Returns to Education in China}

We use China's Urban Household Surveys (UHS) collected by the National Bureau of Statistics (NBS) from 1989 to 2001 from six provinces: Beijing, Guangdong, Liaoning, Shaanxi, Sichuan and Zhejiang. These six provinces are roughly representative of China's different regions. Beijing is in North-Central China, Guangdong and Zhejiang are coastal provinces, Liaoning is in the Northeast, Shaanxi is in the Northwest, and Sichuan is in the Southwest. Table 1 reports sample sizes for each year after excluding 
people younger than 16 , older than 60 , students and the disabled. To reduce bias caused by variations in working hours, when computing wages by educational levels we confine our sample to full-time employees aged from 16 to 60, and we exclude individuals who are self-employed or re-employed retired workers. The size of the resulting full-time wage worker sample is about 6,000-7,000 individuals in each year (Table 1).

The wage measure is the annual wage, including base wages, bonuses, and subsidies. The UHS data does not include information on working hours, making it impossible to calculate an hourly wage. All wages are in 1988 yuan, deflated using provincial CPIs. Throughout the paper we focus on three years: 1990, 1995 and 2000. The years 1990 and 2000 correspond to China's population censuses, the most accurate source of employment data. The mid-year 1995 was roughly at the end of the first spurt in rapidly rising returns to education (Park et al. 2008). For each year of data, we also include the adjacent two years of data in order to increase sample size and smooth out short-run fluctuations.

To carry out the supply and demand analysis below, the total labor force must be disaggregated into a number of educational groups. We classify education levels into three groups: "college" refers to college-educated and above, including three-year vocational colleges and post-graduate education, "senior high" includes graduates of senior high school and three- or two-year vocational and technical high schools, and “junior" includes those completing junior high school and below. ${ }^{3}$

Table 2 presents wages in logarithm by educational levels. The wages of all three

\footnotetext{
${ }^{3}$ The issues arising in disaggregating the labor force have been discussed by Hamermesh (1993) and Katz and Autor (1999). One simple approach is to break up the work force into two groups of particular interest, such as "high" and "low" education (equivalents), or "young" and "old", or men and women. This approach was used by Katz and Murphy (1992), Baldwin and Cain (1997), and Autor et al. (1998), etc. The advantage of this approach is it is simple to implement and the estimates are easy to interpret, but much information is lost. Another approach is to divide the labor force into a large number of cells, typically by sex, education, age/experience groups. The advantage of this approach is that it uses much more information on the nature of changes in wage structure; however it requires strong assumptions about functional form and substitutability of different groups. Bound and Johnson (1992) adopt the latter approach to classify the labor force into 32 groups defined by gender, experience and educational level.
} 
educational levels increased over the period, with the college-educated gaining the most, followed by senior high school graduates. Those with junior high school education and below gained the least. To control for other factors influencing wages, we run regressions of wages on education levels and other personal characteristics (potential experience and potential experience squared, sex, provincial dummy variables). The resultant wage differentials by educational level in different years and their changes form 1990 to 1995 and from 1995 to 2000 are reported in Table 3.

As can be seen from Table 3, the wage differentials between college education and senior high school education and between senior high school education and junior high school education both experienced dramatic increases in the 1990s. However, there were some notable differences between 1990-95 and 1995-2000 and with respect to the levels of education being compared. First, the wage differential widened faster between senior high school and junior high than between college and senior high school in both periods. Secondly, the wage differential widened faster from 1995 to 2000 than from 1990 to 1995, especially for the wage differential between senior high school and junior high school graduates. The wage differential between senior high school and junior high school graduates was $3.5 \%$ in 1990 . This differential more than tripled to $11.5 \%$ in 1995 and again more than doubled to $22.8 \%$ in 2000 . In comparison, the wage differential between college educated and senior high school started at a much higher level, at 22.1\% in 1990, and increased at a much moderate rate, to $27.6 \%$ in 1995 and $34.1 \%$ in 2000 . The goal of this paper is to explain these patterns and trends.

\section{Conceptual Framework}

Our conceptual framework is based on Bound and Johnson (1992), with modifications to fit our context. The aggregate labor force is composed of $I$ educational groups employed in $S$ sectors of employment, defined by industry and ownership 
categories.

Following Bound and Johnson (1992), $W_{i s}$ is the wage of education group $i$ (i=college, senior high, or junior high and below) in sector $s$, and is the product of a competitive wage $W_{i c}$ for each education group and a relative wage rent $R_{i s}$ for working in sector $s$ :

$$
W_{i s}=W_{i c} R_{\text {is }}
$$

If the non-pecuniary attributes of employment in all sectors are identical and nothing causes wages to deviate from their competitive norm, the wage rents $\left(R_{i s}\right.$ 's $)$ will all be identically equal to one. However, in general wage differentials do exist across sectors (Krueger and Summers, 1988; Healwege, 1992; Zhao, 2002). Taking the logarithm of both sides of equation (1) and denoting logs with lower case letters, the log wage of group $i$ in sector $s$ can be decomposed into two additive parts:

$$
w_{i s}=w_{i c}+r_{i s} \text {. }
$$

Averaging both sides of equation (1') across all sectors, we get:

$$
w_{i}=w_{i c}+r_{i}=w_{i c}+\sum_{s} r_{i s} \phi_{i s}
$$

where $w_{i}$ is the average $\log$ wage of group $i$ and $r_{i}=\sum_{s} r_{i s} \phi_{i s}$ is the wage rent enjoyed by group $i$, where $\boldsymbol{\phi}_{\boldsymbol{i}}$ is the employment share of group $i$ in sector $s\left(\boldsymbol{\phi}_{\boldsymbol{i}}=N_{i s} / N_{i}\right.$ where $N_{i s}$ is the number of workers in demographic group $i$ in sector $s$ and $N_{i}$ is the total number of workers in group $\imath$.

Totally differentiating equation (2), we get the following:

$$
d w_{i}=d w_{i c}+d r_{i}
$$

Thus, any change in wage differentials between educational groups is caused either by changes in wage rents or by changes in competitive wages. The change in wage rent can be written as follows: 


$$
d r_{i}=\sum_{s}\left(\phi_{i s} d r_{i s}+r_{i s} d \phi_{i s}\right)=\sum_{s} \phi_{i s} d r_{i s}+\sum_{s} r_{i s} d \phi_{i s}
$$

This decomposition has two elements: changes in relative wages of economic sectors, $\sum_{s} \phi_{i s} d r_{i s}$, or "wage effects", and changes in the distribution of employment across economic sectors, $\sum_{s} r_{i s} d \phi_{i s}$, or "weight effects".

Assuming that the wage rent in sector $s$ is identical for each educational group $\left(r_{i s}=r_{s}\right)$, we consider the two dimensions of industry and ownership type. Thus, we can decompose the wage rent into industrial wage rents and ownership wage rents as follows: ${ }^{4}$

$$
\begin{aligned}
& r_{i}=\sum_{s=1}^{S} r_{s} \phi_{i s}=\sum_{j=1}^{J} \sum_{o=1}^{O} r_{j o} \phi_{i j o}=\sum_{j=1}^{J} \sum_{o=1}^{O}\left(r_{j o}-r_{j}+r_{j}\right) \phi_{i j o} \\
& =\sum_{o=1}^{O} \sum_{j=1}^{J}\left(r_{j o}-r_{j}\right) \phi_{i j o}+\sum_{j=1}^{J} r_{j} \phi_{i j}=r_{i}^{O}+r_{i}^{J}
\end{aligned}
$$

Here, subscript $j$ indexes industry and subscript $o$ indexes ownership type; $\boldsymbol{r}_{\boldsymbol{j}}$ is the wage rent rate for industry $j$ and ownership type $o, \boldsymbol{r}_{j}$ is the average wage rent in industry $j, \phi_{i j}$ is the fraction of group $i$ in industry $j$ and ownership type $0, \phi_{i}$ is the fraction of education group $i$ in industry $j, r_{i}^{O}=\sum_{o=1}^{O} \sum_{j=1}^{J}\left(r_{j o}-r_{j}\right) \phi_{i j o} \quad$ is the ownership wage rent, and $r_{i}^{J}=\sum_{j=1}^{J} r_{j} \phi_{i j}$ is the average industry wage rent enjoyed by group $i$.

Assuming that the industrial wage rent rate $\boldsymbol{r}_{j}$ and ownership wage rent rate $\boldsymbol{r}_{\boldsymbol{c}}$ are determined independently, namely that $r_{j o}=r_{j}+r_{o}$, then the ownership wage rent enjoyed by group $i$ can be defined as $r_{i}^{O}=\sum_{o=1}^{O} r_{o} \phi_{i o}$. The definition of sectoral wage rent

\footnotetext{
${ }^{4}$ This assumption implies that wage rents are only related to characteristics of sector s and not workers' education levels, in other words that they do not reflect selection effects.
} 
enjoyed by group $i$ then can be simplified as follows:

$$
r_{i}=\sum_{o=1}^{O} r_{o} \phi_{i o}+\sum_{j=1}^{J} r_{j} \phi_{i j}=r_{i}^{O}+r_{i}^{J}
$$

Totally differentiating this equation yields the following expression:

$$
d r_{i}=d r_{i}^{O}+d r_{i}^{J}=\left(\sum_{o=1}^{O} \phi_{i o} d r_{o}+\sum_{o=1}^{O} r_{o} d \phi_{i o}\right)+\left(\sum_{j=1}^{J} \phi_{i j} d r_{j}+\sum_{j=1}^{J} r_{j} d \phi_{i j}\right)
$$

Using equation (4), we can separately calculate changes in industrial wage rents $d r_{i}{ }^{J}$ and changes in ownership wage rents $d r_{i}{ }^{C}$, and each of these can be further decomposed into a wage effect and weight effect.

Following Bound and Johnson (1992), we can use the following expression derived from a fully specified demand and supply system to decompose the change in competitive wages for group $i$ :

$$
d w_{i c}=(1-1 / \sigma) d\left(\ln b_{i}\right)+(1 / \sigma) d\left(\ln D_{i}\right)-(1 / \sigma) d\left(\ln N_{i}\right)
$$

where $d w_{i c}$ is the change in the competitive wage of group $i, d \ln N_{i}$ is the change in relative supply of workers in group $i, d n D_{i}$ is the change in relative demand for workers in group $i$ due to shifts in product demand across industries, $d \ln \left(b_{i}\right)$ is the change in relative general technical efficiency of group $i$, and $a$ is the constant elasticity of substitution among educational groups (which can range from 0 to positive infinity).

Equation (5) states that changes in the relative competitive wage of group $i$ workers depend positively on the change in relative technical efficiency $d\left(\ln b_{i}\right)$, negatively on the relative supply change $d\left(\ln N_{i}\right)$, and positively on the change in the demand for products that use group $i$ workers more intensively in their production $d\left(\ln D_{i}\right)$. The impact of each factor on wages depends upon the elasticity of intrafactor substitution.

Plugging equations (4) and (5) into equation (3), we present the final equation for decomposing changes in the relative wage of each educational group: 


$$
d w_{i}=(1-1 / \sigma) d\left(\ln b_{i}\right)+(1 / \sigma) d\left(\ln D_{i}\right)-(1 / \sigma) d\left(\ln N_{i}\right) \quad+\left(d r_{i}^{O}+d r_{i}^{J}\right)
$$

This equation states that a change in the wages of group $i$ relative to the mean wage or the wage of another educational group can be decomposed into four sources: changes in wage rents, changes in relative labor supply, changes in relative labor demand due to shifts in product demand, and changes in relative technological efficiency.

\section{Results}

\subsection{Wage Rents}

We can use a discrete form of equation (4) to calculate changes in wage rents over time. As noted above, these changes include changes in relative wage levels across industries or ownership types, i.e., wage effects, and changes in the educational composition of employment in high- and low-wage industries and ownership types, i.e., weight effects. The share of group $i$ in industry $j$ or in ownership type $o$ in each year can be computed directly from the data, but we need to estimate the wage rents. Assuming that the industrial and ownership wage rents are determined independently, we can use the following regression to estimate the wage rents of group $i$ in industry $j$ or ownership type $o$ (the $\boldsymbol{r}_{j}$ and $\boldsymbol{r}$ ):

$$
\ln W_{k}=\alpha_{0}+\sum_{i} \alpha_{i} G_{k i}+\sum_{j} \gamma_{j} S_{k j}+\sum_{o} \gamma_{o} S_{k o}+\sum_{p} \beta_{p} P_{k p}+\sum_{t} \beta_{t} T_{k t}+\varepsilon_{k}
$$

Here, $\ln W_{k}$ is the $\log$ real wage of individual $k, G_{k i}$ are a set of dummy variables capturing individual characteristics $i$, e.g., sex, experience, and education, $S_{k j}$ are dummy variables for industries $j, S_{k o}$ are dummy variables for ownership types $o, P_{k p}$ are dummy variables for provinces $p, T_{t}$ are dummy variables for years $t,{ }^{5}$ and $z_{k}$ is the error term. The estimated coefficients on the dummies for industries $\left(\gamma_{\rho}\right)$, capture the industrial

${ }^{5}$ To smooth time effects, we define years as moving averages, for example, data for year 1990 includes 1989, 1990 and 1991. 
wage premium relative to the reference group, and the deviation of the estimated $\gamma_{j}$ 's from their mean value $\bar{\gamma}$ in each period is the wage rent associated with industry $j$ $\left(r_{j}=\gamma_{j}-\bar{\gamma}\right) .^{6} \quad$ Ownership wage rents are calculated in analogous fashion.

Categorization of industries in the NBS urban household survey varies in different years. We aggregate the industries into 10 categories that can be consistently defined over all years. Estimated wage rents for industrial sectors are reported in columns 1 to 3 of Table 4. Not surprisingly, monopoly industries such as finance and insurance, transportation, and postal and telecommunications services consistently enjoyed above average wage rents while decentralized and competitive industries such as manufacturing, retail trade and food catering had below-average wages. The data also confirm anecdotal observations that government agencies and semi-governmental social service sectors (education; research; culture, mass media, and health care; and sports and social welfare) have enjoyed considerable gains in wages over time.

The distributions of employment by educational group among industries are reported in columns 4 to 12 of Table 4 . It is easy to see that workers with less education tend to work in low-wage industries. Nearly half of all workers with junior high school education or below were in manufacturing, and another 18 percent worked in the retail and catering industry. Over time, these workers increasingly worked in the social service industry, reaching 10 percent in 2000. Although these three industries also absorbed a large share of senior high school graduates, the percentages were relatively lower. Senior high school graduates increasingly entered into high-paying sectors such as medical care, finance and insurance, and government or semi-government agencies. For college graduates, although nearly one quarter were employed in manufacturing, nearly 40

\footnotetext{
${ }^{6} \bar{\gamma}$ is the weighted average of the estimated coefficients on industry dummy variables: $\bar{\gamma}=\sum_{j=0}^{J-1} \phi_{j} \gamma_{j}$, where $J=10$ is the total number of industrial categories; $\gamma_{j}$ is the proportion of workers employed in industry $j$; and $\gamma_{c}$ of the base industry is set to zero.
} 
percent worked in educational institutions and government or semi-governmental agencies that enjoyed relatively high wage rents.

It is not obvious at first sight whether high-wage industries expanded or contracted, or whether workers with less education left or entered low-wage industries with increasing frequency over time. In columns 2 to 4 of Table 5 , we calculate the total effects of changes in industrial wage rents on wage differentials by educational groups and decompose the effects into wage and weight effects.

The total effect of changes in relative industrial wage rents is to increase the returns to education. In both periods and for both college versus high school graduates and high school versus junior high school, wage effects dominate weight effects. Inspecting the results more carefully yields some interesting observations. From 1990 to 1995, the effect of changes in industry wage rents was similarly positive for the college-senior high and senior-junior high wage differentials while weight effects were inconsequential. However, from 1995 to 2000, changes in industry wage rents strongly favored the college-educated, and this was caused mainly by intensified selection of the college-educated into high-wage industries, or weight effects. This change in inequality dynamics in the latter period could reflect the fact that college graduates increasingly looked for jobs on their own instead of relying on government assignment. It could also reflect the increasing prevalence of "jumping into the sea," whereby those working in the government and state sectors left for more lucrative jobs in the financial or private sectors.

An important part of the economic transition in China has been liberalization of wage setting in the state sector, including state-owned enterprises (SOEs) as well as government and semi-government institutions. It is thus of interest to examine whether state sector rents existed independently of industry rents and how changes in such rents influenced wage differentials across educational groups. The estimated $\boldsymbol{r}_{\mathbf{c}}$ 's are reported 
in columns 1 to 3 in Panel B of Table 4. The employment distribution of the three educational groups across ownership types are described in columns 4 to 12 . It is immediately obvious that the state sector has enjoyed large, positive wage rents, and that these rents have changed little from 1990 to 2000.

As for the industry wage rents, we calculate the effect of changes in ownership wage rents on the relative wage of different education groups, and decompose it into wage effects and weight effects. Results are reported in columns 5 to 7 of Table 5 . They show that changes in ownership wage rents were negative but very small from 1990 to 1995. Interestingly, wage effects were actually positive, indicating a growing wage premium from being employed in the state sector, but weight effects were negative as more educated workers left the state-owned sector (see Table 4). From 1995 to 2000, however, the wage effect became negative, indicating that wage differentials associated with ownership types shrank. The weight effect remained negative for the wage of senior high relative to junior high and below, but turned positive for the wage of college relative to senior high school graduates. The latter result suggests that college-educated workers returned to the state-sector or were less likely to leave or be let go during the process of state-sector restructuring that occurred during the late 1990s.

\subsection{Labor supply}

A natural index for capturing the changes in relative labor supply of different education groups is the labor-supply-shift index, $S U P_{i}$, the proportionate change in group is share of aggregate labor force, measured as the change in the logarithm of the shares:

$$
S U P_{i}=\Delta\left(\ln \phi_{i}^{s}\right)
$$

Here, $\phi_{i}^{s}=N_{i}^{s} / N^{s}$ is the fraction of education group $i$ in the total labor force. 
The educational composition of the labor force from the UHS data is reported in columns 1 to 3 of Table 6. One major limitation of the UHS data is that the surveys sample only registered urban residents, excluding migrants who lack permanent resident status even though migrants increasingly compete with local residents in urban labor markets. Using 1990 and 2000 census data from the same provinces, which do include migrants, we re-estimate the relative shares of labor in different education groups. We interpolate the fraction of migrants in the labor force in 1995 by assuming that the change in the fraction of migrants changes linearly from 1990 to 2000. As reported in Table 6, the fraction of migrants in the urban labor force was $7.61 \%$ in $1990,18.71 \%$ in 1995 and $29.81 \%$ in 2000 . The composition of migrants by education level is reported in columns 4 to 6 of Table 7. The labor supply composition by education group after including migrants are reported in the columns 7 to 9 of Table 7 . Then the change in the relative supply of each group $i\left(S U P_{i}\right)$ is calculated using equation (8) and the results are reported in column 1 of Table 9.

As seen in Table 7, if we look at local permanent residents alone, the rise in educational attainment has been very rapid. However, if we include migrants, the rise is much less dramatic. From 1995 to 2000, the decline in the share of junior high school graduates among local urban residents was completely offset by the inflow of migrants with junior high school education or lower. The SUP for the period 1990 to 1995 reveals that the relative supply of senior high school to junior school graduates and that of the college to senior high school graduates both went up, by 14 percent and 30 percent, respectively. However, from 1995 to 2000, the situation changed drastically due to the surge of migration, which led to a decline of 6 percent in the relative supply of senior high school graduates to junior high school graduates or below. Over the same period, the supply of the college educated relative to senior high school graduates increased by 15 percent. 


\subsection{Shifts in Product Demand}

Changes in the structure of output lead to changes in the structure of inputs, in particular the skill composition of labor demand. Under the assumptions that relative labor productivity across industries remains constant and the labor market clears in each period, changes in the employment distribution across industries must reflect shifts in the structure of product demand. Following Freeman (1975) and Katz and Murphy (1992), we use the average employment growth by industry weighted by the initial employment share of each educational group to define an index $E M P_{i}$ to measure the effect of product demand shifts on relative labor demand:

$$
E M P_{i}=\sum_{j} \Delta\left(\ln \phi_{j}\right) \phi_{i j}
$$

Here, $\phi_{j}$ is the share of employment in industry $j$ and $\Delta\left(\ln \phi_{j}\right)$ is the proportionate change in the employment share in industry $j$.

Table 8 describes the changes in the structure of industries over time. The distribution of employment across industries, $\phi_{j}$, computed from the UHS data which includes only local permanent residents is reported in columns 1 to 3. As before, we adjust the industrial employment shares using the share of migrants and their distribution across industries according to the census data in 1990 and 2000. The migrant shares of the urban work force are presented in Table 6, the employment distribution of migrants across industries are described in columns 4 to 6 of Table 8 , and the adjusted employment distributions of all urban workers are reported in columns 7 to 9 . The change in industrial employment shares $\left(\Delta\left(\ln \phi_{j}\right)\right)$ are in columns 10 and 11 .

Industries such as education and media, and semi-government organizations, which employ college-educated workers more intensively experienced a relative contraction, especially from 1995 to 2000 . The index EMP, the values of which are reported in 
columns 3 and 4 of Table 9, can be taken as a proxy for the change in the structure of labor demand, $d\left(\ln D_{j}\right)$. The values of this index are all negative for both 1990-95 and 1995-2000, suggesting that shifts in product demand increased the relative demand for unskilled workers. However, changes in relative employment growth rates among industries also could be caused by changes in labor supply structure, which would lead to bias in the decomposition of relative wage changes.

An alternative approach that can avoid this bias is to estimate a discrete version of product-demand-shift index, $D E M_{i}$ :

$$
D E M_{i}=\Delta\left(\ln D_{i}\right)=\sum_{j} \phi_{i j} \Delta\left(\ln x_{j}\right)
$$

where $x_{j}$ is the true relative demand for products produced by industry-j based on consumer preferences (Bound and Johnson, 1992). Unfortunately, these $x_{j}$ are unobserved. However, the unknown $\Delta\left(\ln x_{j}\right)$ can be estimated as coefficients $d \ln x_{j}$ in the following equation:

$$
d\left(\ln \phi_{i j}\right)=\left(1-\phi_{i j}\right) d\left(\ln x_{j}\right)-\sum_{k \neq j} \phi_{i k} d\left(\ln x_{k}\right)+(\sigma-1)\left[d\left(\ln \left(b_{i j} / b_{i}\right)\right)\right]
$$

where the subscript $i$ indexes educational groups $(i=1,2,3), j$ indexes industries, $b_{i j}$ is an index of the technical efficiency of group $i$ in industry $j ; b_{i}$ is the average technical efficiency of group $i$ across all industries; and $d\left(\ln b_{i j} / \ln b_{i}\right)$ is the deviation of the growth rate of technical efficiency of group $i$ in industry $j$ from the average growth rate of technical efficiency for group $i$. If we assume that technical changes are the same across industries for all the groups, the mean of $d\left(\ln b_{i j} / \ln b_{i}\right)$ will equal to 0 , and the last term in equation (11) can be treated as a random error with mean zero. Under this assumption, which we justify below, we can obtain unbiased estimates for $d \ln x_{j}$ by estimating equation (11) using OLS.

The results of this estimation are presented in columns 7 and 8 of Table 8 . Based on 
these estimates for $\Delta\left(\ln x_{j}\right)$, the product-demand-shift index $D E M_{i}$ 's is calculated using equation (10) and are reported in columns 5 and 6 of Table 9. Similar to EMP, nearly all of the values for DEM are negative, implying that changes in product demand across industries caused the relative demand for unskilled labor to increase. Part of this change in production could have resulted from international trade. Since China has a more abundant supply of less-educated workers, comparative advantage dictates that China should specialize in producing goods that use low-skilled labor more intensively. This contrasts with developed countries like the U.S., where trade has reduced the relative demand for unskilled workers, contributing to rising inequality based on skill level. Another part of the story may originate from China's structural transition from a planned to a market-oriented economy. Whereas state-owned firms faced distorted prices and tended to be capital- and skill-intensive, the rapidly growing non-state sector faced market-determined wages and less access to credit, leading to employment decisions more in line with China's comparative advantage.

\subsection{Skill-Biased Technical Change}

Generally speaking, technological progress can occur in a particular industry or in all industries; thus, skill-biased technical changes that affect the relative demand for workers with different skill levels can be industry-specific or general. In the estimation of $\Delta\left(\ln x_{j}\right)$ above, we treated the effect of industry-specific technical change (the last term in equation (11)) as a random error. If this assumption about the error term does not hold, the estimation of $d \ln x_{j}$ could be biased because faster technological progress in some industries could cause a larger increase in the demand for labor in those industries. In the U.S., it has been suggested that the effects of spurts of innovation on the relative demand for different groups could vary across industries (Bound and Johnson, 1992). 
To test whether technical change actually varies across industries, we follow Bound and Johnson (1992) and decompose the growth rate of technology efficiency of group $i$ in industry $j$ as follows:

$$
d\left(\ln b_{i j}\right)=\left\{\begin{array}{ll}
c_{i 0}+c_{i 1} & \text { if } j \text { in } J^{\prime} \\
c_{i 0} & \text { otherwise }
\end{array} .\right.
$$

Here J' is the subset of industries hypothesized to have a different rate of growth than a comparison set of industries, $\mathrm{c}_{\mathrm{i} 0}$ is the average growth rate in technical efficiency of group $i$ in the comparison industries, and $\mathrm{c}_{\mathrm{i} 1}$ is the difference between the growth rate of technical efficiency in the two groups. If there is no significant influence of industry-specific technical efficiency change, then the average growth rate of technology efficiency for the two groups should be the same, equal to $\mathrm{c}_{\mathrm{i} 0}$.

The average growth rate of technology efficiency for group $i$ can thus be expressed as follows:

$$
d\left(\ln b_{i}\right)= \begin{cases}c_{i 0}+\sum_{j} \phi_{i j} c_{i 1}=c_{i 0}+\Phi_{i J} c_{i 1} & \text { if } \mathrm{jin} \mathrm{J}^{\prime} \\ c_{i 0} & \text { if jnot in } \mathrm{J}^{\prime}\end{cases}
$$

where $\Phi_{i J^{\prime}}=\sum_{j \in J^{\prime}} \phi_{i j}$ is the proportion of education group i's employment in the subset of industries J'. The industry-specific technical efficiency change of group $i$ in industry $j$ is:

$$
d\left[\ln \left(b_{i j} / b_{i}\right)\right]=\left\{\begin{array}{ll}
c_{i 1}\left(1-\Phi_{i J^{\prime}}\right) & \text { if } \mathrm{j} \text { in } \mathrm{J}^{\prime} \\
0 & \text { if j not in } \mathrm{J}^{\prime}
\end{array}=c_{i 1}\left(D_{J^{\prime}}-\Phi_{i J^{\prime}}\right),\right.
$$

where $\mathrm{D}_{\mathrm{J}}$, is a vector of dummy variables for whether each industry is part of $\mathrm{J}$ '. Substituting equation (14) into equation (11), we get:

$$
d\left(\ln \phi_{i j}\right)=\left(1-\phi_{i j}\right) d\left(\ln x_{j}\right)-\sum_{k \neq j} \phi_{i k} d\left(\ln x_{k}\right)+(\sigma-1) c_{i 1}\left(D_{J^{\prime}}-\Phi_{i J^{\prime}}\right)
$$

By choosing a specific industry set J' and one or more educational groups, we can estimate this equation using OLS, and estimate values for $(\sigma-1) c_{i 1}$. If those values are 
not significantly different from zero, we cannot reject the null hypothesis that there are no industry-specific technical changes. ${ }^{7}$

We test a wide range of industries and educational groups in this way. For example, we first test whether the manufacturing industry enjoyed a rate of technological change that was different than other industries. We find that there are no educational groups for which this is the case. The p-value for the joint exclusion test that none of the three educational groups exhibits a different rate of technological change in manufacturing is 0.85 for the period 1990 to 1995 and 0.26 for the period 1995 to 2000. Similarly, we tried other industries such as construction; transportation, post, and telecommunication services; wholesale and retail trade \& catering services; public utility management; and social services, both individually and jointly. All the results fail to show that there is any significant industry-specific technology effect for any educational group.

We take this as evidence that all three educational groups have the same growth rate of technological efficiency across industries. One possible explanation for the lack of industry-specific technical change is that economic reforms and institutional changes in the 1990s promoted efficiency similarly in all sectors of the economy rather than in specific industries. Another possibility is that our classification of industries is too broad to capture industry-specific technical change well. Given these findings, we conclude that the previous estimates of $d\left(\ln x_{j}\right)$ are unbiased when estimating equation (11') using OLS.

Given the lack of evidence of industry-specific technical change, we focus attention exclusively on estimating the contribution of general technical change, captured by the term $(1-1 / \sigma) d\left(\ln b_{i}\right)$. The difficulty, of course, is that $b_{i}$ is unobservable. However, the effect of general technical change on the relative wage of an educational group can be approximated by the difference between the change in competitive wage

${ }^{7}$ Given $\sigma>1$, the term $(\sigma-1) \mathrm{c}_{\mathrm{i} 1}$ should be different from zero if group $i$ has different growth rate of technological efficiency (namely, $c_{i 1} \neq 0$ ). Theoretically, it is also possible that $\sigma=1$, however, the likelihood that this equality holds exactly is vanishingly small. 
$d w_{i c}$ and the effects of changes in relative supply and relative demand (see equation (5)).

As seen in equation (5) estimating the impact of relative demand and relative supply on relative wages requires an estimate of the elasticity of substitution $\bar{c}$. One approach is to estimate this parameter directly from the data. We adopt a strategy similar to that of Katz and Murphy (1992), estimating the following time series regression:

$$
\ln \left[W_{i}(t) / W_{i-1}(t)\right]=\alpha_{0}+\alpha_{1} \ln \left[N_{i}(t) / N_{i-1}(t)\right]+\alpha_{2} t+\alpha_{3} \cdot D_{1} \cdot t+\varepsilon
$$

Here $i$ refers to senior high school (college), and $i-1$ refers to junior high school and below (senior high school); $\ln \left[W_{i}(t) / W_{i-1}(t)\right] \quad$ is the relative wage of educational group $i$ compared to education group $i-1$ in year $t, \ln \left[N_{i}(t) / N_{i-1}(t)\right] \quad$ is the relative supply of educational group $i$ compared to education group $i-1$ in year $t, D_{1}$ is a dummy variable which equals 1 if the comparison group is senior vs. junior high school, and 0 if otherwise; $\alpha_{1}=-1 / \sigma$, and $\alpha_{2}+\alpha_{3} \cdot D_{1}$ captures relative changes over time in the demand for each comparison group ${ }^{8}$. The estimate for elasticity of intrafactor substitution $\bar{c}$ can be simply computed from the estimated coefficient $\hat{\alpha}_{1}=1 \hat{/} \sigma$.

For our sample, time $t$ ranges from 1989 to 2001. The OLS estimates for equation (15) are the following:

$$
\begin{aligned}
\ln \left[W_{i}(t) / W_{i-1}(t)\right]= & -50.94-0.367 \ln \left[N_{i}(t) / N_{i-1}(t)\right]+0.0255 t+0.000048 \cdot D_{1} \cdot t \\
& (5.88)(0.092) \\
N=26, R^{2}= & 0.85
\end{aligned}
$$

The results yield an estimate for the elasticity of intra-factor substitution of 2.72 , which appears to be on the high side in comparison to studies of the U.S. ${ }^{9}$ In the

\footnotetext{
${ }^{8}$ Katz and Murphy (1992) estimate the elasticity of the substitution between college and senior high school by running the following linear regression on time series data: $\ln \left[w_{2}(t) / w_{1}(t)\right]=\alpha_{0}+\alpha_{1} \ln \left[N_{2}(t) / N_{1}(t)\right]+\alpha_{2} t+\varepsilon \quad$, where $w_{2}(t) / w_{1}(t), N_{2}(t) / N_{1}(t)$ are the relative wage of college and high school graduates and the relative supply of college to high school labor; $\alpha_{1}=-1 / \sigma$, and $\alpha_{2}$ captures the time trend of relative demand shifts. This regression specification is based on a simple CES technology with two factors (college and high school labor) with changes in relative demand for college versus high school labor being a simple linear time trend.

${ }^{9}$ Bound and Johnson (1992) estimate a second-differenced equation for the market wage. Because of
} 
decomposition section, we use this estimate but also test the sensitivity of results to different assumptions about the elasticity of intra-factor substitution, given the large potential for error in estimation of this type of time-series specification.

\subsection{Decomposition Results}

Using the estimates from previous sections, we can fully decompose the sources of changes in the returns to education in urban China during the 1990 s into four components: changes in wage rents (including industry wage rents and ownership wage rents), changes in relative labor supply, changes in relative demand resulting from changes in production structure, and general technical change. The latter is computed from the residual relative wage changes not explained by relative demand and supply changes, as well as our estimate of the elasticity of substitution among different education groups.

In Table 10, decomposition results are reported separately for the early and late 1990s, and for changes in the relative wages of college versus high school graduates and of high school graduates versus those completing junior high school and below. The results yield a number of interesting findings. First, changes in relative technical change are by far the most important source of rising returns to skill in all time periods and regardless of which education groups are being compared, accounting for between 90 and 291 percent of relative wage increases. However, because the effects of technical change are calculated as residual effects, one must be careful in interpretation. Although skill-biased technical change is likely to be an important part of the story, as evidenced by rapid improvements in technology in China brought about at least partly by inward foreign direct investment, other factors are at play as well. Perhaps most importantly, the institutional transition towards a market economy may have have caused wages to and below), there are only 3 observations and there is no way of running regressions. 
increasingly reflect differences in the productivity of workers and also provided incentives for more educated workers to become more productive (Zhang et al., 2005).

Second, for three of the four decompositions, changes in wage rents are the second most important contributor to relative wage increases, accounting for 21 percent of increasing relative wages of high school graduates versus those with less than high school education in the early 1990s and 28 and 63 percent of increasing relative wages of college versus high school graduates in the early and late 1990s. As described earlier, the larger contribution of wage rents to growing relative returns to college education in the late 1990s and the lack of a contribution of wage rents to rising relative wages of high school graduates versus those without high school education are the result of greater specialization of the college-educated in high rent sectors and low-education workers in low rent sectors, a phenomena driven by the large-scale migration to urban areas of rural migrants with less than high school education during the late 1990s.

Third, changes in relative labor supply and relative labor demand associated with shifts in production structure reduced the relative wages of better educated workers. The only exception is the change in relative supply of high school graduates versus those without high school degrees from 1995 to 2000, when China witnessed a large-scale migration of poorly educated rural workers to the cities. During this period, the falling relative supply of high school graduates accounted for 20 percent of rising relative wages of high school graduates compared to those without high school degrees. For all other periods and education group comparisons, the relative supply of better educated workers increased. The negative effects of these increases were much greater than the negative effects due to shifts in product demand. As a share of relative wage increases of college versus high school graduates, relative supply changes contributed -64 and -82 percent in the early and late 1990 s, compared to -23 and -34 percent contributions from changes in relative demand associated with changing production structure. In the early 1990s, 
relative supply changes contributed -64 percent to increases in the relative wage of high school graduates versus those without high school degrees, compared to -9 percent due to changes in relative demand. As noted earlier, the negative contribution of demand changes to rising returns to education is consistent with expanding international trade, which would be expected in increase the demand for unskilled labor-intensive products, increasing the demand lower educated workers. This negative effect appears to have been even greater in the late 1990s than the early 1990s for the relative wages of college versus high school graduates, perhaps due to significant trade liberalization in the late 1990s as China prepared for WTO accession.

Our final exercise is to examine the sensitivity of our results to the magnitude of the elasticity of substitution of workers from different education groups. As noted earlier, our estimated value of 2.72 is on the high side of estimates for the U.S. (Freeman, 1986), even though many recent studies generally accept that the elasticity of substitution between high-skill and low-skill workers is greater than one in the U.S.(Katz and Murphy, 1992; Bound and Johnson,1992; Autor, Katz, and Kruger, 1998; Katz, and Autor, 1999). In China, one might expect an even lower elasticity of substitution given remaining rigidities in the labor market associated with regulated wage and employment policies in the state sector and policy barriers to spatial mobility. On the other hand, China has a very high literacy rate and production sophistication may be relatively low compared to developed countries, reducing the set of tasks that can only be completed by better educated workers.

In Table 11, we report decomposition results varying the elasticity of substitution from 1.1 to 3 . The first thing to note is that the contribution of wage rents is invariant to assumptions about the elasticity of substitution. Second, increases in the elasticity of substitution increase the contributions of relative supply and demand changes multiplicatively, with the contribution of general technical change adjusting to ensure that 
the total changes add up to actual changes in relative wages. In our case, as the elasticity of substitution increases, the negative effects of relative supply and demand changes both become smaller (less negative) and the estimated positive contribution of technical change falls as well but by proportionately less than the reduced negative effects. As an example, comparing the case of $\sigma=1.1$ with the baseline estimates reported in Table 10, the negative contribution of relative supply changes to the relative wage increase of high school graduates versus those without high school degrees from 1990 to 1995 falls in magnitude from -191 percent to -64 percent, the contribution of relative demand changes falls from -30 percent to -9 percent, and the contribution of technical change falls from 300 to 151 percent. Even at the lowest elasticity of substitution, the positive impact of general technical change on relative wages outweighs the negative effects of changes in relative supply and relative demand. Thus, the main conclusions of the decomposition exercise are robust to changing assumptions about the elasticity of substitution.

\section{Conclusion}

In this paper, we analyze the extent to which recent rapid increases in the returns to education can be explained by four factors: changes in industrial wage rents, changes in relative labor supply, shifts in product demand, and the changes in relative technical efficiency. We find that skill-biased technical progress accounts for most of the rise in returns to education, which we interpret broadly to include changes in available technologies as well as institutional changes associated with economic transition and maturation of China's urban labor market. Changes in industrial wage rents are the second most important contributing factor, while changes in ownership wage rents slightly reduce wage premiums associated with higher educational attainment. The relative supply of highly educated groups increased over time, reducing education 
premiums, except for a reduction in the relative supply of high school graduates to those completing junior high school and below in the late 1990s when rural migration increased significantly. Shifts in demand favoring less skill-intensive products, a pattern consistent with China's comparative advantage, also reduced growth in education premiums but by less than relative supply increases.

The growth in the returns to high school compared to junior high and below outpaced growth in the returns to higher education compared to high school in both periods. This was due to faster expansion of higher education which increased the relative supply of college graduates combined with greater increases in migration of rural workers with lower levels of education to urban areas, as well as shifts in product demand towards low skill-intensive products, which reduced the relative demand for college graduates.

Another distinctive pattern is that increases in the relative wage of high school graduates compared to those not graduating from high school was much faster during 1995-2000 than during 1990-1995. The most important reason for this acceleration was the slowdown in the growth of relative supply of senior versus junior school graduates, again caused by the larger increase in migration in the late 1990s and the greater likelihood that senior high school graduates would go on to college.

One important limitation of the data used in this study is that it only permits industry classifications that are highly aggregated. This may lead to downward bias in the estimated effects of changes in industrial wage rents and of shifts in product demand, and upward bias in the effect of general technical change.

Recent research confirms that the returns to education in urban China continued to increase well into the 2000s (Cai et al, 2008). This is not surprising given that the important factors contributing to rising returns to education in the late 1990s remained prominent in the new century: large-scale rural-to-urban migration, growing prominence 
of international trade and foreign direct investment, expansion of higher education, and increasing market orientation of the labor market. The results of this study thus provide insights that can help identify factors likely to contribute to changes in the returns to education in the future, which will undoubtedly have important implications for inequality, incentives for educational investments, and economic performance. 


\section{References}

Acemoglu, D. (2002), “Technical Change, Inequality, and the Labor Market,” Journal of Economic Literature, 40(1), pp7-22.

Autor, D., Katz, L., and Kruger, A. (1998), “Computing Inequality: Have computers changed the Labor market?” Quarterly Journal of Economics, 113, pp.1169-1213.

Baldwin, Robert E. and Glenn G. Cain (1997), "Shifts in relative wages: the role of trade, technology and factor endowments", Working paper no. 5934 (NBER, Cambridge, MA).

Borjas, G. and Valerie A. (1995), "Foreign Competition, Market Power, and Wage Inequality”, Quarterly Journal of Economics, 110, pp.1075-1110

Bound, J., and Johnson G. (1992), “Changes in the Structure of Wages in the 1980s: An Evaluation of Alternative Explanations,” American Economic Review 82: 371-392.

Cai, Fang, Albert Park, and Yaohui Zhao (2008), “The Chinese Labor Market in the Reform Era,” in Loren Brandt and Thomas Rawski, eds., China's Great Economic Transformation (Cambridge: Cambridge University Press).

Card, D. and DiNardo, J. (2002), Skill Biased Technological Change and Rising Wage Inequality: Some Problems and Puzzles, NBER Working Paper No. 8769, http://www.nber.org/papers/w8769 .

DiNardo, J., Fortin N. and Lemieux T. (1996), "Labor Market Institutions and Distribution of Wages, 1973-1992: A Semiparametric Approach”, Econometrica, 64(5):1001-46

Freeman, R. (1975), "Overinvestment in College Training?" Journal of Human Resources 10:287 311.

Freeman, R. (1986), "Demand for Education", in: O. Ashenfelter and R. Layard, eds., Handbook of Labor Economics, Vol. 1 (North-Holland, Amsterdam).

Freeman, R. (1993), "How much has de-unionization contributed to the rise in male earnings inequality?" in: S. Danziger and P. Gottschalk, eds., Uneven tides (RusseLl Sage, New York).

Freeman, R. and Katz L. (1994), "Rising wage inequality: the United States vs. other advanced countries", in: R. Freeman, ed., Working under different rules (Russell Sage Foundation, New York).

Hanmermesh, Daniel S. (1979), “Econometric Studies of Labor-Labor Substitution 
and their Implications for Policy,” Journal of Human Resources, 14, 518-42.

Hamermesh, Daniel (1993), Labor demand (Princeton University Press, Princeton, NJ).

Healwege, Jean (1992). “Sectoral shift and Inter-industry wage Differentials”, Journal of Labor Economics, Vol. 10, No.1 (Jan 1992), 55-84.

Johnson , G. (1997), “Changes in Earnings Inequality: The Role of Demand Shifts”, Journal of Economic Perspective, 11(2), PP.41-54

Juhn, Chinhui, Kevin M. Murphy, and Brooks Pierce (1993). “Wage Inequality and the Rise in Returns to Skill,” Journal of Political Economy 101(3): 410-442.

Katz, Lawrence and Kevin M. Murphy (1992). "Changes in Relative Wages, 1963-1987: Supply and Demand Factors,” Quarterly Journal of Economics, 107: 35-78

Katz, Lawrence F. and David H. Autor, (1999), “Changes In The Wage Structure And Earnings Inequality”, in O. Ashenfelter and D. Card, eds., Handbook of Labor Economics, vol. 3A, North-Holland, 1999, 1463-1555.

Krueger, A.(1993), "How Computers Have Changed the Wage Structure: Evidence from Mcrodata,1984-1989”, Quarterly Journal of Economics, 110,pp.33-60.

Krueger, Alan B. and Summers, Lawrence H. (1988), "Efficiency Wages and the Inter-Industry Wage Structure”, Econometrica, March 1988, 56, 259-93.

Lemieux, T. (2007), “The changing nature of wage inequality”, NBER working paper, No.13523, http://www.nber.org/papers/w13523.

Park, Albert, Xiaoqing Song, Junsen Zhang, and Yaohui Zhao (2008), “Rising Returns to Skill, Labor Market Transition, and the Growth of Wage Inequality in China”, working paper.

Zhang, Junsen, Yaohui Zhao, Albert Park, Xiaoqing Song (2005), “Economic returns to schooling in urban China,1988 to 2001”, Journal of Comparative Economics, Aug 2005.

Zhao, Yaohui (2002), “Earnings Differentials between State and Non-State Enterprises in Urban China,” Pacific Economic Review, Vol. 7, No. 1, 181-197 
Table 1. Urban Household Survey Sample Size in Six Provinces

\begin{tabular}{lc}
\hline Year & Sample Size \\
\hline 1989 & 6007 \\
1990 & 6574 \\
1991 & 6574 \\
1992 & 8350 \\
1993 & 7472 \\
1994 & 7267 \\
1995 & 7353 \\
1996 & 7219 \\
1997 & 7373 \\
1998 & 7146 \\
1999 & 7037 \\
2000 & 7350 \\
\hline
\end{tabular}

Table 2. Mean Log Wages by Education Group, 1990, 1995 and 2000 (1988 yuan)

\begin{tabular}{lccr}
\hline & 1990 & 1995 & 2000 \\
\hline Junior high school and below & 7.38 & 7.66 & 7.79 \\
Senior high school & 7.43 & 7.81 & 8.10 \\
College and above & 7.63 & 8.09 & 8.38 \\
\hline
\end{tabular}

Table 3. Wage Differentials and Changes in Relative Wage, 1990, 1995, 2000

\begin{tabular}{lccccc}
\hline & \multicolumn{3}{c}{ Wage Differentials } & \multicolumn{2}{c}{ Changes } \\
\hline & 1990 & 1995 & 2000 & $1990-1995$ & $1995-2000$ \\
Senior high vs. junior high and below & 0.035 & 0.115 & 0.228 & 0.080 & 0.113 \\
College and above vs. senior high & 0.221 & 0.276 & 0.341 & 0.056 & 0.065 \\
\hline
\end{tabular}




\begin{tabular}{|c|c|c|c|c|c|c|c|c|c|c|c|c|}
\hline & \multirow{2}{*}{\multicolumn{3}{|c|}{ Wage rent }} & \multicolumn{9}{|c|}{ Employment distribution } \\
\hline & & & & \multicolumn{3}{|c|}{ Junior high and below } & \multicolumn{3}{|c|}{ Senior high } & \multicolumn{3}{|c|}{ College and above } \\
\hline & 1990 & 1995 & 2000 & 1990 & 1995 & 2000 & 1990 & 1995 & 2000 & 1990 & 1995 & 2000 \\
\hline & (1) & (2) & (3) & (4) & $(5)$ & $(6)$ & (7) & $(8)$ & $(9)$ & $(10)$ & (11) & $(12)$ \\
\hline \multicolumn{13}{|l|}{ A. Industry } \\
\hline Manufacturing & -0.006 & -0.045 & -0.081 & 51.00 & 50.65 & 45.02 & 37.02 & 35.83 & 36.41 & 27.07 & 27.09 & 24.49 \\
\hline Construction & 0.060 & 0.077 & -0.020 & 3.43 & 4.96 & 4.26 & 2.13 & 3.82 & 3.44 & 1.26 & 2.98 & 3.42 \\
\hline Transportation, post and telecom. services & 0.068 & 0.100 & 0.123 & 8.38 & 6.81 & 8.76 & 6.46 & 6.80 & 7.61 & 3.43 & 3.61 & 4.24 \\
\hline Wholesale/retail trade \& catering services & -0.024 & -0.091 & -0.116 & 18.57 & 18.55 & 17.90 & 15.07 & 16.82 & 16.35 & 6.11 & 8.13 & 8.50 \\
\hline Public utility management and social services & -0.009 & 0.089 & -0.030 & 4.68 & 6.11 & 10.23 & 3.89 & 4.81 & 9.44 & 1.38 & 2.73 & 5.41 \\
\hline Health care, sports and social selfare & 0.046 & 0.083 & 0.181 & 2.18 & 1.89 & 2.00 & 7.21 & 6.35 & 5.35 & 8.08 & 6.32 & 6.02 \\
\hline Education, research, culture and mass media, & -0.012 & 0.050 & 0.167 & 2.94 & 3.42 & 3.07 & 10.55 & 9.42 & 7.06 & 26.67 & 21.24 & 17.59 \\
\hline Finance and insurance & 0.100 & 0.253 & 0.212 & 0.62 & 0.49 & 0.73 & 2.71 & 3.60 & 3.08 & 2.32 & 3.07 & 6.14 \\
\hline Government agencies and social organizations & -0.010 & 0.042 & 0.118 & 4.85 & 4.99 & 4.26 & 12.29 & 11.02 & 8.39 & 21.08 & 22.96 & 22.15 \\
\hline Geological exploration and other industries & -0.053 & -0.037 & -0.125 & 3.35 & 2.12 & 3.76 & 2.68 & 1.53 & 2.87 & 2.60 & 1.87 & 2.03 \\
\hline \multicolumn{13}{|l|}{ B. Ownership } \\
\hline Non-SOEs & -0.128 & -0.139 & -0.116 & 0.34 & 0.32 & 0.38 & 0.17 & 0.19 & 0.27 & 0.05 & 0.08 & 0.15 \\
\hline Government and SOEs & 0.040 & 0.038 & 0.043 & 0.66 & 0.68 & 0.62 & 0.83 & 0.81 & 0.73 & 0.95 & 0.92 & 0.85 \\
\hline
\end{tabular}


Table 5. Changes in Relative Wage and Wage Rents, 1990 to 1995 and 1995 to 2000

\begin{tabular}{|c|c|c|c|c|c|c|c|c|}
\hline & \multirow{3}{*}{$\begin{array}{c}\Delta \\
\text { Rel. } \\
\text { wage } \\
(1)\end{array}$} & \multicolumn{3}{|c|}{ Industrial wage rent } & \multicolumn{3}{|c|}{ Ownership wage rent } & \multirow{3}{*}{$\begin{array}{c}\text { Total } \\
\text { wage } \\
\text { rent } \\
(8)\end{array}$} \\
\hline & & $\begin{array}{l}\text { Wage } \\
\text { effect }\end{array}$ & $\begin{array}{c}\text { Weight } \\
\text { effect }\end{array}$ & Total & $\begin{array}{l}\text { Wage } \\
\text { effect }\end{array}$ & $\begin{array}{l}\text { Weight } \\
\text { effect }\end{array}$ & Total & \\
\hline & & (2) & (3) & (4) & (5) & (6) & (7) & \\
\hline \multicolumn{9}{|l|}{ 1990-1995 } \\
\hline Senior vs. junior & 0.08 & 0.02 & 0.002 & 0.021 & 0.001 & -0.005 & -0.004 & 0.017 \\
\hline College vs. senior & 0.056 & 0.02 & -0.003 & 0.018 & 0.001 & -0.003 & -0.002 & 0.016 \\
\hline \multicolumn{9}{|l|}{$1995-2000$} \\
\hline Senior vs. junior & 0.113 & 0.023 & -0.017 & 0.006 & -0.002 & -0.005 & -0.007 & -0.001 \\
\hline College vs. senior & 0.065 & 0.03 & 0.012 & 0.042 & -0.002 & 0.003 & -0.001 & 0.041 \\
\hline
\end{tabular}

Note: "Senior-junior" denotes senior high school vs. junior high school and below, and “College-senior” denotes college and above vs. senior high school.

Table 6. Share of Migrants in the Labor Force and Employment in Urban Areas in 6 Provinces

\begin{tabular}{lccc}
\hline & 1990 & 1995 & 2000 \\
& $(1)$ & $(2)$ & $(3)$ \\
\hline Labor force & 7.61 & 18.71 & 29.81 \\
Employment & 7.78 & 19.90 & 32.01 \\
\hline
\end{tabular}

Note: * Under the assumption that the increase of migrants is linear during 1990-2000, the estimation of the fractions of migrants in 1995 is based on the following equation: fmig1995=fmig1990+(fmig2000-fmig1990)/10*5, where fmig1990, fmig1995 and fmig2000 respectively stand for the fraction of migrants in 1990,1995 and 2000.

Table 7. Labor Force Composition in Urban China

\begin{tabular}{lccccccccc}
\hline & \multicolumn{3}{c}{ Local residents } & \multicolumn{3}{c}{ Migrants } & \multicolumn{3}{c}{ All } \\
& 1990 & 1995 & 2000 & 1990 & 1995 & 2000 & 1990 & 1995 & 2000 \\
& $(1)$ & $(2)$ & $(3)$ & $(4)$ & $(5)$ & $(6)$ & $(7)$ & $(8)$ & $(9)$ \\
\hline Junior high and below & 49.57 & 38.73 & 33.32 & 80.74 & 79.27 & 77.79 & 51.94 & 46.32 & 46.58 \\
Senior high & 37.15 & 40.86 & 41.71 & 17.20 & 17.50 & 17.80 & 35.63 & 36.49 & 34.59 \\
College and above & 13.28 & 20.41 & 24.97 & 2.07 & 3.24 & 4.41 & 12.43 & 17.20 & 18.84 \\
\hline
\end{tabular}


Table 8. Adjusted Relative Labor Supply and Derived Demand Indexes by Industry, 1990-1995 and 1995-2000

\begin{tabular}{|c|c|c|c|c|c|c|c|c|c|c|c|c|c|}
\hline \multirow[b]{2}{*}{ Industry } & \multicolumn{3}{|c|}{$\begin{array}{c}\text { Local Urban } \\
\text { Resident Workers }\end{array}$} & \multicolumn{3}{|c|}{ Migrant Workers } & \multicolumn{3}{|c|}{ Employed in urban area } & \multicolumn{2}{|c|}{$\Delta\left(\ln \phi_{j}\right)$} & \multicolumn{2}{|c|}{$\Delta\left(\ln x_{j}\right)$} \\
\hline & 1990 & 1995 & 2000 & 1990 & 1995 & 2000 & 1990 & 1995 & 2000 & $\begin{array}{c}1990- \\
1995 \\
(10)\end{array}$ & $\begin{array}{c}1995- \\
2000 \\
(11)\end{array}$ & $\begin{array}{c}1990- \\
1995 \\
(12)\end{array}$ & $\begin{array}{c}1995- \\
2000 \\
(13)\end{array}$ \\
\hline Manufacturing & 42.60 & 39.69 & 36.12 & 42.48 & 50.80 & 59.12 & 42.59 & 41.90 & 43.48 & -0.016 & 0.037 & -0.009 & -0.053 \\
\hline Construction & 2.65 & 4.08 & 3.70 & 18.47 & 13.25 & 8.03 & 3.88 & 5.91 & 5.09 & 0.419 & -0.149 & 0.472 & -0.077 \\
\hline Transportation, post and telecom. services & 7.00 & 6.14 & 7.11 & 4.92 & 3.75 & 2.58 & 6.84 & 5.66 & 5.66 & -0.189 & 0.000 & -0.097 & 0.192 \\
\hline Wholesale/retail trade \& catering services & 15.59 & 15.67 & 14.82 & 18.82 & 19.25 & 19.67 & 15.84 & 16.38 & 16.37 & 0.034 & -0.001 & 0.060 & -0.009 \\
\hline Public utility management and social services & 3.94 & 4.88 & 8.65 & 6.78 & 7.11 & 7.44 & 4.16 & 5.32 & 8.26 & 0.246 & 0.440 & 0.273 & 0.614 \\
\hline Health care, sports and social welfare & 4.83 & 4.63 & 4.43 & 0.88 & 0.73 & 0.58 & 4.53 & 3.86 & 3.20 & -0.160 & -0.187 & -0.162 & -0.104 \\
\hline Education, research, culture and mass media & 8.97 & 9.58 & 8.50 & 4.98 & 3.21 & 1.44 & 8.66 & 8.31 & 6.24 & -0.041 & -0.287 & -0.127 & -0.231 \\
\hline Finance and insurance & 1.62 & 2.30 & 3.11 & 0.14 & 0.20 & 0.27 & 1.50 & 1.88 & 2.20 & 0.224 & 0.157 & 0.183 & 0.122 \\
\hline Government agencies and social organizations & 9.80 & 11.20 & 10.62 & 2.23 & 1.46 & 0.70 & 9.21 & 9.26 & 7.44 & 0.006 & -0.219 & -0.024 & -0.163 \\
\hline Geological exploration and other industries & 3.00 & 1.83 & 2.94 & 0.30 & 0.24 & 0.18 & 2.79 & 1.51 & 2.06 & -0.611 & 0.306 & -0.470 & 0.493 \\
\hline Total & 100 & 100 & 100 & 100 & 100 & 100 & 100 & 100 & 100 & - & - & - & - \\
\hline
\end{tabular}


Table 9. Changes in Relative Supply and Relative Labor Demand Due to Shifts in Product Demand across Industries

\begin{tabular}{lrrr}
\hline Years and education groups & $\begin{array}{r}\text { SUP } \\
(1)\end{array}$ & $\begin{array}{r}\text { EMP } \\
(2)\end{array}$ & $\begin{array}{r}\text { DEM } \\
(3)\end{array}$ \\
\hline 1990-1995 & & & \\
Senior high vs. junior high and below & 0.139 & -0.004 & -0.02 \\
College and above vs. senior high & 0.301 & -0.013 & -0.036 \\
1995-2000 & & & \\
Senior high vs. junior high and below & -0.06 & -0.045 & -0.027 \\
College and above vs. senior high & 0.145 & -0.071 & -0.059 \\
\hline
\end{tabular}

Table 10. Decomposition of Change in Relative Wages, 1990-1995 and 1995-2000

\begin{tabular}{|c|c|c|c|c|c|c|c|}
\hline & \multirow{2}{*}{$\begin{array}{c}\Delta \text { Rel. } \\
\text { wage } \\
\text { (1) }\end{array}$} & \multicolumn{3}{|c|}{$\Delta$ Wage rents } & \multirow{2}{*}{$\begin{array}{l}\text { SUP } \\
\text { (5) }\end{array}$} & \multirow{2}{*}{$\begin{array}{c}\text { DEM } \\
\text { (6) }\end{array}$} & \multirow{2}{*}{$\begin{array}{c}\Delta \text { Tech } \\
\quad(7)\end{array}$} \\
\hline & & $\begin{array}{l}\text { All } \\
(2)\end{array}$ & $\begin{array}{l}\text { Industry } \\
\text { (3) }\end{array}$ & $\begin{array}{l}\text { Owner. } \\
\text { (4) }\end{array}$ & & & \\
\hline \multicolumn{8}{|c|}{ A. Change in relative wage } \\
\hline \multicolumn{8}{|l|}{ 1990-1995 } \\
\hline Senior-junior & 0.080 & 0.017 & 0.021 & -0.004 & -0.051 & -0.007 & 0.121 \\
\hline $\begin{array}{l}\text { College-senior } \\
\text { 1995-2000 }\end{array}$ & 0.056 & 0.016 & 0.018 & -0.002 & -0.111 & -0.013 & 0.163 \\
\hline Senior-junior & 0.113 & -0.001 & 0.006 & -0.007 & 0.022 & -0.01 & 0.102 \\
\hline College-senior & 0.065 & 0.041 & 0.042 & -0.001 & -0.053 & -0.022 & 0.099 \\
\hline \multicolumn{8}{|c|}{$\begin{array}{l}\text { B. Percentage of change in relative wage } \\
1990-1995\end{array}$} \\
\hline Senior-junior & 100 & 21.25 & 26.25 & -5.00 & -63.75 & -8.75 & 151.25 \\
\hline $\begin{array}{l}\text { College-senior } \\
1995-2000\end{array}$ & 100 & 28.57 & 32.14 & -3.57 & -198.21 & -23.21 & 291.07 \\
\hline Senior-junior & 100 & -0.88 & 5.31 & -6.19 & 19.47 & -8.85 & 90.27 \\
\hline College-senior & 100 & 63.08 & 64.62 & -1.54 & -81.54 & -33.85 & 152.31 \\
\hline
\end{tabular}

Note: "Senior-junior" denotes senior high school vs. junior high school and below, and "College-senior" denotes college and above vs. senior high school. 
Table 11. Sensitivity of Decomposition Results to the Elasticity of Substitution (\% of Change in Relative Wage)

\begin{tabular}{|c|c|c|c|c|c|c|}
\hline$\sigma$ and years & $\begin{array}{l}\text { Comparison } \\
\text { groups }\end{array}$ & $\begin{array}{c}\Delta \text { Wage } \\
\text { premium } \\
(1)\end{array}$ & $\begin{array}{l}\Delta \text { Wage } \\
\text { rents } \\
(2)\end{array}$ & $\begin{array}{c}\text { Effect of } \\
\text { SUP } \\
(3)\end{array}$ & $\begin{array}{c}\text { Effect of } \\
\text { DEM } \\
(4)\end{array}$ & $\begin{array}{c}\text { Effect of } \\
\Delta \text { tech. } \\
\text { (5) }\end{array}$ \\
\hline \multicolumn{7}{|l|}{$\sigma=1.1$} \\
\hline \multirow[t]{2}{*}{ 1990-1995 } & Senior- junior & 100 & 21.25 & -191.13 & -30.00 & 299.88 \\
\hline & College- senior & 100 & 28.57 & -591.25 & -77.14 & 739.82 \\
\hline \multirow[t]{2}{*}{$1995-2000$} & Senior- junior & 100 & -0.88 & 58.41 & -28.67 & 71.15 \\
\hline & College- senior & 100 & 63.08 & -245.38 & -108.92 & 391.23 \\
\hline \multicolumn{7}{|l|}{$\sigma=1.5$} \\
\hline \multirow[t]{2}{*}{ 1990-1995 } & Senior- junior & 100 & 21.25 & -115.83 & -16.67 & 211.25 \\
\hline & College- senior & 100 & 28.57 & -358.33 & -42.86 & 472.62 \\
\hline \multirow[t]{2}{*}{$1995-2000$} & Senior- junior & 100 & -0.88 & 35.40 & -15.93 & 81.42 \\
\hline & College- senior & 100 & 63.08 & -148.72 & -60.51 & 246.15 \\
\hline \multicolumn{7}{|l|}{$\sigma=2$} \\
\hline \multirow[t]{2}{*}{ 1990-1995 } & Senior- junior & 100 & 21.25 & -86.88 & -12.50 & 178.13 \\
\hline & College- senior & 100 & 28.57 & -268.75 & -32.14 & 372.32 \\
\hline \multirow[t]{2}{*}{$1995-2000$} & Senior- junior & 100 & -0.88 & 26.55 & -11.95 & 86.28 \\
\hline & College- senior & 100 & 63.08 & -111.54 & -45.38 & 193.85 \\
\hline \multicolumn{7}{|l|}{$\sigma=2.5$} \\
\hline \multirow[t]{2}{*}{ 1990-1995 } & Senior- junior & 100 & 21.25 & -69.50 & -10.00 & 158.25 \\
\hline & College- senior & 100 & 28.57 & -215.00 & -25.71 & 312.14 \\
\hline \multirow[t]{2}{*}{$1995-2000$} & Senior- junior & 100 & -0.88 & 21.24 & -9.56 & 89.20 \\
\hline & College- senior & 100 & 63.08 & -89.23 & -36.31 & 162.46 \\
\hline \multicolumn{7}{|l|}{$\sigma=3$} \\
\hline \multirow[t]{2}{*}{ 1990-1995 } & Senior- junior & 100 & 21.25 & -57.92 & -8.33 & 145.00 \\
\hline & College- senior & 100 & 28.57 & -179.17 & -21.43 & 272.02 \\
\hline \multirow[t]{2}{*}{$1995-2000$} & Senior- junior & 100 & -0.88 & 17.70 & -7.96 & 91.15 \\
\hline & College- senior & 100 & 63.08 & -74.36 & -30.26 & 141.54 \\
\hline
\end{tabular}

Note: "Senior-junior" denotes senior high school vs. junior high school and below, and "College-senior" denotes college and above vs. senior high school. 